\title{
Effect of supplementation of malted ragi (Eleusine coracana) beverage on nutritional status of sportswomen
}

\author{
Megha Bansal and Navjot Kaur
}

\begin{abstract}
Ragi, the low cost millet, is a rich source of dietary fibre, calcium and phytochemicals with nutraceutical potential. Ragi contains about 6-13 per cent protein, 1-2 per cent fat, 65-75 per cent carbohydrates, 15-20 per cent dietary fibre and 2.53.5 per cent minerals. Thirty sportswomen in the age group of 18 to 22 years were selected from Punjab Agricultural University, Ludhiana to determine the effect of supplementation of malted ragi (Eleusine coracana) beverage on nutritional status of sportswomen. During experimental period sportswomen were supplemented with $250 \mathrm{ml}$ of most acceptable beverage for the period of four months. The results revealed that the developed beverage was having good amount of energy $(218.19 \mathrm{kcal})$, protein $(11.78 \mathrm{~g})$, fat $(6.81 \mathrm{~g})$, calcium $(172.6 \mathrm{mg})$, iron $(3.73 \mathrm{mg})$ and phosphorus $(102.2 \mathrm{mg})$ per 100 $\mathrm{g}$. The mean daily food intake of cereals, pulses, roots and tubers, fruits, milk and milk products, fats and oils and sugars increased significantly $(\mathrm{p} \leq 0.05)$ after experimental period. Also significant increase was observed $(\mathrm{p} \leq 0.05)$ in the intake of energy, protein, carbohydrates, calcium, iron, phosphorus, vitamin A, folic acid and vitamin $\mathrm{C}$ after the experimental period. The increase in the haemoglobin, TIBC and serum calcium of the sportswomen after experimental period was increased to $12.30 \mathrm{~g} / \mathrm{dl}, 457.01 \mu \mathrm{g} / \mathrm{dl}$ and $9.77 \mathrm{mg} / \mathrm{dl}$, respectively. Therefore, ragi in malted form can be utilized for the development of highly nutritious beverage.
\end{abstract}

Key Words : Sportswomen, Malted ragi beverage, Supplementation, Nutrients, Haemoglobin, Nutraceutical

How to cite this article : Bansal, Megha and Kaur, Navjot (2019). Effect of supplementation of malted ragi (Eleusine coracana) beverage on nutritional status of sportswomen. Food Sci. Res. J., 10(1): 12-21, DOI : 10.15740/HAS/FSRJ/10.1/12-21. Copyright@ 2019: Hind Agri-Horticultural Society.

(Email : meghabansa1283@gmail.com)

Associate Authors' :

Navjot Kaur, Department of Food and Nutrition, Punjab Agricultural

University, Ludhiana (Punjab) India

(Email : drnavjotgill@gmail.com) 